\title{
THE PERCEPTION OF THE LEADER'S PERSONALITY WITH EMPHASIS ON ITS DEVELOPMENT DURING THE PAST DECADES
}

\section{åLUKÁŠ MAZÁNEK, 'ZDENKA KONEČNÁ}

Brno University of Technology, Faculty of Business and Management, Kolejní 2906/4, Královo Pole, Brno, Czech Republic email: ${ }^{a}$ Mazanek@fbm.vutbr.cz, ${ }^{b}$ Konecna@fbm.vutbr.cz

Abstract: The field of leadership and management science as well has a very deep roots. The leader personality is perceived in the context of specific leadership style of the working groups. This academic study is aimed to search the consequences of leader personality perception in the historical framework and economy development. Significant epochs are examined from a historical and economic perspective to find a connection with the gradual emergence of theoretical ideas. Ideas that laid the foundations of managerial and economic theory, up to current state of knowledge in the field of company leadership. Thanks to identification of particular approaches and the field of company leadership. Thanks to identification of particular approaches and schools of thought the study allow to clearly understand the perception of leader personality development in the last decades. The study creates the wide theoretical background for future research in the field of currant theoretical leadership approaches
within company management. Keywords: Leadership, leader personality, management, development, theories, approaches.

\section{Introduction}

The leaders accompanying our society since time immemorial. Earlier in the role of elders, tribal chieftains, powerful monarchs of valiant generals to current leaders of international corporations (Bláha, 2013). The aim is to study the historical development of leadership within management, until today, when both of these areas have a vital role in the orientation of company in the right direction and its continuous development. The article will discuss the various theoretical approaches, in relation to historical events, which in many cases initiated the creation of the relevant theory. Leadership is currently by many authors considered as part of the management and constitutes one of its main functions, together with planning, organizing and control (Koontz, 1998). From the historical perspective leadership is associated with human civilization since time immemorial, while what we call management is a product of the last century in response to emergence of a large number of diverse organizations, that was necessary to adequately manage (Kotter, 1990). The aim will be to define the basic differences between management and leadership, but also find a way to unify these approaches in the context of company ideal, when a good manager is also a great leader. Such a state is currently very welcome, as it contributes to the fulfillment of a vision and helping company succeed in global competitiveness.

\section{Management theory}

The managerial skills, were very important for mankind already thousands years ago. Commonly mentioned example is the construction of the Egyptian pyramids, where it was necessary to organize the work up to 10000 workers for a period of 20 years. Also, the Great Chinese Wall was built thousands years ago, and its creation required managerial personality capable of planning and coordinating the work of many people. In Europe can be traced unique managerial skills in building cathedrals and many other monumental buildings during the Middle Ages. Later, in recent history begins with the onset of the industrial society became increasingly important managing objects of industrial nature (Blažek, 2014).

Adam Smith (1776) in his work "The Wealth of Nations" suggested the division of labor into smaller, better manageable units, which should result in a significant improvement of economic output. It is obvious that many civilizations have been able to use this simple idea, but Smith was the first who wrote it and published. He proposed manufacturing process improvements in metallurgy, where every worker should hold any other function in iron production, to achieve significant growth in production (Scott, 2005). Specifically, according to Smith, the productivity is increasing if there are connected three basic factors. The first is the growth of dexterity and work skills of craftsmen, as well as better use of working time and as the last factor improving productivity he indicates improvement of tools and their adaptation to the working performance (Fuchs, 2007). Implementation of these improvements, are considered as the first step of the industrial revolution (Scott, 2005). In this period there were due to the technical development significant changes in manufacturing processes. Industrial Revolution meant big changes in agriculture and productivity due to new discoveries and the use of new inventions. Also social structure of agriculture changed, landowners have routinely hired workers who did not own the land. There were emerged new manufactories, in an urban environment due to transformation of handicraft production in processes with developed division of labor activity and thanks to massive new energy sources and technical solutions (Hálek, 2014).

The beginnings of management are therefore associated with the development of production and the end of the guild organization. One of the first theoretical works, are works by Henry Poor and Daniel McCallum (1860), they defined management as the synthesis of organization, communication and information. They verify theoretical knowledge at the railway company in New York and Erie Railroad. Their recommendations included e.g. leave managing to experts and publish financial results. Unfortunately, some of their findings provoked displeasure at the company's owners and McCallum was released (Sládek, 2013).

When defining the history of economy theory with an emphasis on the figure of a manager, it is appropriate follow-up analysis of the historical context since 1871. In this year during marginalist revolution, was formulated the theory of marginal utility in a very sophisticated and comprehensive form, allowing to create a new system of economic thought. This new system of political economy was significantly different, from the still dominating Ricardo and Mill (1817) theory of political economy. Until now classics focused on the supply side of the market and therefore on the theory of costs, they were interested in long-term problems and overlook the importance of market demand to determine the relative prices. By contrast, marginalists were focused just on the demand side of the market. In framework of economic analysis, they focused almost all of them attention on the allocation of scarce resources, while the classics were primarily interested in economic growth. Revolution was also in the methodology, because it started using the marginal values. Marginalist method enables to analyze the allocation of economic resources and showed that the allocation of scarce resources is effective, when it respects the rule of balancing marginal values. Marginal analysis also brought to the economics new tools and techniques, and opened space for mathematisation of economics.

So far, the classics have seen the company as a structure constituted of social classes - landowners, capitalists and workers. While examining relationships and the distribution of the national product among them. The capitalist was the creator of the payroll funds. Conserve his profits, which changed into the payroll fund and payroll fund was subsequently a source of employment and capital accumulation. He invested resources, led by Smith's invisible hand of the market and stimulate economic growth. In this new era, in the new marginalist economics, is a central figure the consumer. The consumer is seen as the primary bearer of a sovereign economic decision, his preferences are the primary driving force, while the producers register these preferences and fulfill his wishes (Holmann 2001). The process of expanded reproduction based on innovation, which in the initial stage was carried by the owners of capital, now moved to the competence of managers (Sojka, 2004). In this new economy paradigm, created by marginalist, figure of the capitalist disappear and disintegrate in the role of rentier, entrepreneur and manager (Holmann 2001).

In the beginning, the older neo-classical economists approached the firm as a compact, indivisible entity, without tackling its internal structure and operations. By contrast are formed "Managerial theory of the firm", which emphasize, separation of ownership from management in the modern large companies. 
These theories focus on mutual relations and economic behavior of stakeholders within the company. The main attention of management theory is focused on motivating managers to ensure the long-term position in the market and maintain long-term stable profits. Owners in the role of shareholders, on the contrary, prefer high dividends and high market value of the shares (Sojka, 2000).

According to Němeček and Zich (2004), manager at the beginning of the 20th century, held various positions. We expect the following five functions of the main functions that a manager in this period performed. In terms of business functions, it means building sales and marketing strategies, market research and competitive assessments. Production functions means that the manager was tasked to ensure the production of products in the required quantity, quality and time at minimum cost. Technical function is represented in connection with efforts to invest in sustainable development and innovation, to maintain market share and staying ahead of the competition. Economic function instructs the manager to create economic analysis, tactics and strategy company decision, based on established economic parameters. The last mentioned is HR function that is associated with the recruitment, personnel development and key personnel stabilization.

When we focus on particular development of these views on the management in the 20th century, schools of thought could be divided according to Bělohlávek (1996) in next tab. 1.

Table 1: Development of management approaches in the 20th century. Own work in accordance to Bělohlávek (1996) Němeček and Zich (2008), Kennedy (1991).

\begin{tabular}{|c|c|c|c|}
\hline Time range & Approach & Description & Key thoughts \\
\hline $\begin{array}{l}\text { Till the } 20 \\
\text { years of the } \\
\text { 20th century }\end{array}$ & $\begin{array}{l}\text { Mechanistic } \\
\text { approach }\end{array}$ & \begin{tabular}{|} 
Pattern for designing \\
organizational systems were \\
accurate functioning machines. \\
Mechanistic organization was \\
founded on a perfectly \\
configured system, accurately \\
defining the roles, \\
competencies and \\
responsibilities, where human \\
performing routine work as part \\
of a great machine.
\end{tabular} & $\begin{array}{l}\text { Theory of bureaucracy } \\
\text { (Max Weber) } \\
\text { Classical management } \\
\text { (Henry Fayol, F. W. } \\
\text { Mooney and Lyndall } \\
\text { Urwick } \\
\text { Scientific management } \\
\text { (Frederick Taylor) }\end{array}$ \\
\hline $\begin{array}{c}20-30 \text { years } \\
\text { of the } 20 \text { th } \\
\text { century }\end{array}$ & $\begin{array}{l}\text { School of } \\
\text { Human } \\
\text { Relations }\end{array}$ & $\begin{array}{c}\text { Elton Mayo, brought new ideas } \\
\text { in organizational theory. He } \\
\text { drew attention to importance of } \\
\text { social relationships and job } \\
\text { satisfaction, for the success of } \\
\text { the organization and } \\
\text { performance of staff. He is also } \\
\text { the author of Hawthorn studies, } \\
\text { where with other researchers } \\
\text { studied the factors that affect } \\
\text { productivity. }\end{array}$ & $\begin{array}{c}\text { New ideas in } \\
\text { organizational theory } \\
\\
\text { Hawthorn studies } \\
\text { (Mayo, 1933) }\end{array}$ \\
\hline $\begin{array}{c}40-50 \text { years } \\
\text { of the } 20 \text { th } \\
\text { century }\end{array}$ & $\begin{array}{l}\text { Humanistic } \\
\text { approach }\end{array}$ & \begin{tabular}{|c|} 
During this period, attention \\
shifts to humans. As the major \\
working stimul, is considered to \\
satisfy the personal \\
development of the individual.
\end{tabular} & $\begin{array}{c}\text { Theory X and Y } \\
\text { (McGregor, 1960) } \\
\\
\text { Theory of hierarchy of } \\
\text { needs (Maslow, 1943) }\end{array}$ \\
\hline $\begin{array}{l}60-70 \text { years } \\
\text { of the 20th } \\
\text { century }\end{array}$ & $\begin{array}{l}\text { Modern } \\
\text { opinions }\end{array}$ & $\begin{array}{c}\text { The requirement of modern } \\
\text { times is "keep it simple and } \\
\text { short". The aim is to search for } \\
\text { a simple essence, which easily } \\
\text { explains the functioning of } \\
\text { organizations, their problems } \\
\text { and show how these may be } \\
\text { solved. }\end{array}$ & $\begin{array}{l}\text { Theory of contingency, } \\
\text { general systems theory, } \\
\text { population ecology, } \\
\text { cybernetic principles } \\
\text { and theory of "Z". }\end{array}$ \\
\hline $\begin{array}{l}80-90 \text { years } \\
\text { of the 20th } \\
\text { century }\end{array}$ & $\begin{array}{l}\text { Postmodern } \\
\text { Approach }\end{array}$ & \begin{tabular}{|c} 
Postmodernism is trying to \\
avoid all the simplification, call \\
into question big theories, \\
accepts the complexity of the \\
world and offers custom \\
solutions to partial problems. \\
Traditional aversion for \\
changes is necessary to replace \\
by the friendly attitude to \\
chaos. Its essential role, here \\
begins to have correctly applied \\
the concept of change \\
management. World experts are \\
engaged in the study of Asian \\
well-performing organizations \\
and then recommend ways, to \\
revitalize European \\
organizations. \\
\end{tabular} & $\begin{array}{l}\text { Understanding the need } \\
\text { of change management } \\
\text { concept application. }\end{array}$ \\
\hline
\end{tabular}

Management of the late twentieth century, is usually associated with the development of human capital. The main focus is on the customer, who must be satisfied and pressure is growing with innovation and marketing.

At the beginning of the 21st century the new global information technology of global society and prolongation of positive changes, in the concept of human capital captive entire management (Geršlová, 2012). According to Kareš (2006) an important position gaining, "knowledge management" in the context of the acquisition, evaluation and use of knowledge, which can become an important comparative advantage. Knowledge begin to be considered as the primary key factor of production. More and more organizations transferred to a "virtual model", characterized by high degree of flexibility. The aim of the virtual institution is after integrating modern knowhow of cooperating firms and experts to create added value for the customer, which ultimately leads to a significant increase in competitiveness. Organizations whose cooperation is based on the principles of classical vertical organization with departments such as marketing, production, development etc. should become a history. As the business grows, there is a significant increase in the number of decision-making levels and longer lines of communication which ultimately leads to the bureaucratization of the organization and the loss of competitiveness.

\section{Leadership theory}

Historically, search for a leader characteristics or his properties last for centuries. One of the oldest thoughts about leadership can be found in works that are dated back over 2,500 years e.g. The Art of War by Sun-ć (Steigauf, 2011). Next up thinkers in ancient Greece try to theoretically define leader personality. Socrates was convinced, that leadership is closely related to the situation and largely depend on the knowledge of a particular leader (Bláha, 2013). His student Platon perceived power and leadership in connection with the role and concept of state. He recommends recognize and accept as a leader, person who are best able to rule. According to Platon, ideal ruler is enlightened philosopher, who formed the company based on good laws, by contrast the worst and illegal, he considered tyranny (Lukas and Smolík, 2008). Platon focused, on individual characteristic traits as morality, justice, virtue and righteousness. These qualities should be applied to the state level, where they lead to the development of a community (Störig, 2007). Ancient authors perceived as the most important character and competence for the leaders. They argue that people who cannot manage their desires, will disturb the relationship between leader and the followers, and are therefore unfit to lead. On the other hand, those with good character attracts others and uplift them. Striving for perfection, therefore, requires both character and competence. In conclusion the ancient philosophy say that leader requires continuous development of mind, body and soul, to obtain a complete spectrum of courage in the intellectual, physical and moral field (Steigauf, 2011).

In the 15th century Niccolo Machiavelli dealt with the concept of leadership. Unlike many of his predecessors, including Platon and Aristotle, he did not come from ethical, but practical and realistic facts. In his book "The Prince" provide advices for the political leaders how to acquire and maintain power. He was aware, that the ideal monarch should be benevolent and humanity, but also acknowledges that it is not always possible and beneficial (Lukas, Smolík, 2008). Machiavelli in his work, for example, states that it is not necessary that the ruler endowed with all good qualities, but it is necessary to make it appear that it has. As the author is a proponent of leadership through deceit and intrigue, triumph of force over intelligence. This approach has been according to Crainer (2000) a daily reality in the industries dependent on internal politics. But Crainer notes, that machiavellian management methods no longer have a place in modern management. Ceases to apply, that the end justifies the means, and in vogue gets gentle art of persuasion. Most managers today understand that business have a different meaning than just maximizing profits. Thus we see a return to the age of intelligence, against which Machiavelli rebelled. In 
modern history (19-20 century) were the first concepts based on the thought of leadership as innate ability. These theories are known as "Theory of great personalities" and "Theories of properties" (Steigauf, 2011). In the mid-20th century, are beginning to discover other alternative theories based on researches in the field of leader's behavior. Part of the researches identify individual leadership styles and in the 60s, was developed the managerial grid model. In response to the Theory of properties was created the Situational theory, while some researchers have merged the situational and property approaches in so called Contingency theory. In the 70s have been discovered Transactional and Transformational theories (Steigauf, 2011). However, researchers focus on leadership until nowadays. Bass (1997) presents approaches based on a charismatic leader. Messick and Kramer (2005), are dealing with concepts of social identity in leadership, theories of exchange between the leader and his followers and the psychodynamic approach to leadership. Other researchers Pearce and Conger (2003) describe approaches based on sharing leadership in the whole group, it is called Shared leadership and includes eighteen partial approaches. Among these approaches belongs e.g. determination of expectations theories, self-leadership, followership, and shared knowledge theories. As another contemporary concept Brown and Trewino (2006) mentioned Ethic leadership. They describe ethical leadership as an approach based on mutual communication between leader and co-workers (Two - Way communication). Important is to support of colleagues and the ability to make good decisions. Specific leader's traits identified through interviews are honesty, integrity and ethical behavior. They also cite, as essential characteristics kindness and consistent individuality, which are doing fair and balanced decision. Next up authentic leadership which describe leaders as personalities who acquire authenticity (credibility) by using selfconfidence, self-acceptance and trusted relationships and actions. The integrity of leader personality is perceived as the observance of moral principles and actions based on them (Gardner et al, 2005). The last mentioned concept in this study is Spiritual leadership. This approach introduces values and behaviors that intrinsically motivate employees who feel, that they are part of a greater whole (Fry, 2003). Reave (2005) explains that it is necessary for the leader to embodied the spiritual values that include integrity. Leader is an example of a credible personality that develops these values in society.

For clarity, development of leadership theories in 19th and 20th century is shown in the following table 2, where the main schools of thought are divided, according to Crainer (2000) into nine theories.

Table 2: The leadership development in the 19 and 20th century. Own work in accordance to Crainer (2000). Yammarino et al., (2005), Dansereau et al., (2013).

\begin{tabular}{|c|c|c|}
\hline $\begin{array}{c}\text { Name of } \\
\text { theory }\end{array}$ & Description school of thought & $\begin{array}{c}\text { Original articles related to } \\
\text { descripted theory }\end{array}$ \\
\hline $\begin{array}{c}\text { Great } \\
\text { personality } \\
\text { theory }\end{array}$ & $\begin{array}{c}\text { Theory dominated in the 19th and } \\
\text { 20th centuries. It is based on the idea } \\
\text { that leaders are born with leadership } \\
\text { skills unexplained and unreachable } \\
\text { for ordinary mortals. }\end{array}$ & $\begin{array}{c}\text { On heroes, hero-worship and the } \\
\text { heroic", Carlyle, T. (1888), } \\
\text { Some Findings Relevant to the } \\
\text { Great Man Theory of Leadership } \\
\text { (Borgatta, 1954) }\end{array}$ \\
\hline $\begin{array}{c}\text { Theory of } \\
\text { properties }\end{array}$ & $\begin{array}{c}\text { Effort to trace the characteristics of } \\
\text { leaders led to researches focused on } \\
\text { personality of people in the leader } \\
\text { role. Unfortunately, very few } \\
\text { publications that are aimed to define } \\
\text { the common characteristics of } \\
\text { leaders, reach to the same } \\
\text { conclusions. }\end{array}$ & $\begin{array}{c}\text { Social psychology (Bird, 1940) } \\
\text { A Research Approach to } \\
\text { Leadership Problems } \\
\text { (Lewin, 1944) }\end{array}$ \\
$\begin{array}{c}\text { The nature of leadership } \\
\text { (Barnard, 1948) }\end{array}$ \\
\hline $\begin{array}{c}\text { Theories of } \\
\text { power and } \\
\text { influence }\end{array}$ & $\begin{array}{c}\text { This approach focuses on the } \\
\text { networks of power and influence, } \\
\text { which leader creates. The underlying } \\
\text { assumption is that all roads lead to the } \\
\text { leader, but neglect the importance of } \\
\text { corporate culture and the role of } \\
\text { followers. }\end{array}$ & $\begin{array}{c}\text { A Review of the relationships } \\
\text { between personality and } \\
\text { performance in small groups } \\
\text { (Mann 1959) }\end{array}$ \\
\hline Behaviorist \\
theory & $\begin{array}{c}\text { The main emphasis is on real activity } \\
\text { of leaders, rather than their properties. } \\
\text { Among its proponents include } \\
\text { creators of managerial grid Blake and } \\
\text { Mouton. }\end{array}$ & $\begin{array}{c}\text { A Dynamic Theory of } \\
\text { Personality (Lewin, 1935) } \\
\text { The functions of the executive } \\
\text { (Barnard, 1938), Leadership, } \\
\text { membership and organization, } \\
\text { (Stogdil, 1950) }\end{array}$ \\
\hline
\end{tabular}

\begin{tabular}{|c|c|c|}
\hline $\begin{array}{l}\text { Situational } \\
\text { theory }\end{array}$ & $\begin{array}{l}\text { Within situational theory, leadership } \\
\text { is rather seen as a special type of } \\
\text { situation, than a kind of personality. } \\
\text { The underlying assumption is that } \\
\text { different circumstances require } \\
\text { different forms of leadership. }\end{array}$ & \begin{tabular}{|c|}
$\begin{array}{c}\text { Situational behavioral approach } \\
\text { to the study of educational } \\
\text { leadership } \\
\text { Hencley (1973) } \\
\\
\text { Educational administration: } \\
\text { Theory, research, and practice } \\
\text { (Hoy \& Miskel, 1987) }\end{array}$ \\
\end{tabular} \\
\hline $\begin{array}{c}\text { Contingency } \\
\text { theory }\end{array}$ & $\begin{array}{c}\text { Contingency theory is based on the } \\
\text { situational theory and tries to pick } \\
\text { situational variables, that could better } \\
\text { determine a suitable leadership style, } \\
\text { which is appropriate in the } \\
\text { circumstances. }\end{array}$ & $\begin{array}{c}\text { A path goal theory effectiveness. } \\
\text { (House, 1971) } \\
\text { A critique of the Vroom-Yetton } \\
\text { contingency model of leadership } \\
\text { behavior (Field, 1979) }\end{array}$ \\
\hline $\begin{array}{l}\text { Transactional } \\
\text { theory }\end{array}$ & $\begin{array}{c}\text { The emphasis is placed on the } \\
\text { relationship between leader and } \\
\text { followers. There are investigated the } \\
\text { mutual benefits arising from the } \\
\text { relationship based on mutual } \\
\text { exchanges (transactions), where the } \\
\text { leader offers some resources or } \\
\text { rewards in exchange for e.g. loyalty } \\
\text { of followers and their recognition of } \\
\text { leader authority. }\end{array}$ & $\begin{array}{c}\text { Leadership. (Burns, 1978), } \\
\text { Leadership and performance } \\
\text { beyond expectation (Bass 1985) } \\
\text { Biography and the assessment of } \\
\text { transformational leadership at the } \\
\text { world class level (Bass et al, } \\
\text { 1987) }\end{array}$ \\
\hline $\begin{array}{l}\text { Attributional } \\
\text { theory }\end{array}$ & $\begin{array}{c}\text { Approach as well called attribution } \\
\text { theory, gives new meaning to } \\
\text { followership, because it focus on the } \\
\text { factors that underlie perception of } \\
\text { leadership abilities of leader by his } \\
\text { followers. }\end{array}$ & $\begin{array}{c}\text { A Typology of Attribution } \\
\text { Leadership Research (McElroy, } \\
\text { 1982) }\end{array}$ \\
\hline $\begin{array}{c}\text { Transformatio } \\
\text { nal theory }\end{array}$ & \begin{tabular}{|} 
Unlike transactional models of \\
leadership are based on external \\
stimulating of motivation, this \\
approach is focused on the internal \\
motivation of followers. The \\
emphasis is on the involvement of \\
followers, rather than on their \\
submissiveness. Transformational \\
leader can therefore be characterized \\
as proactive and innovative visionary.
\end{tabular} & $\begin{array}{c}\text { Leadership. (Burns, 1978), } \\
\text { Leadership and performance } \\
\text { beyond expectation (Bass 1985) } \\
\text { Biography and the assessment of } \\
\text { transformational leadership at the } \\
\text { world class level (Bass et al, } \\
\text { 1987) }\end{array}$ \\
\hline
\end{tabular}

\section{Discussion and conclusions}

People needed to organize and manage the work of many individuals since time immemorial. Usually there was a leader, who planned and coordinated activities. Leader acts according to his own experiences and proven advices from elders. This approach was common when it was necessary to e.g. build monumental buildings in the antiquity or middle ages.

In search of historical and economic context is identified a crucial historical fact, which had a huge impact on the development of management science. It was marginalist revolution in 1871. In this new economic paradigm created by the marginalist, figure of the capitalist disappear and disintegrates in the role of rentier, entrepreneur and manager (Holmann 2001). So it is for the first time when economic science officially meets the figure of manager. There were consequently a number of approaches that deal with effective management e.g. Taylor's principles, Ford's experience in the automotive industry or the Bat'a factories in Czechoslovakia.

The history of leadership also has very deep roots. Particularly mentioned the period of the first theories of ancient Greece, a specific view of Niccolo Machialelli in the 15th century, and the emergence of many theories in the 20th century.

According to (Bláha, 2013) management and leadership are constantly evolving and move closer together. Although the concept of leadership overlaps significantly management, these approaches are based on different tools application in business environment, that should be used appropriately to achieve a balance among them.

The aim of this study was to provide an overview of ideas and theoretical approaches in the field of development of leadership within management. The goal was to determine the theoretical approaches that have shaped the perceptions of management and leadership in such form as they are currently understood.

Development of management theory was described especially from the middle ages until nowadays. With special focus on development in 20th century, where was almost every decade new theory created. 
Given the focus of the future research on the application of the leadership concept in the context of human resource management, attention was paid to the development of leadership as well. Again with emphasis on the last century where many new leadership theories were published based on the empirical researches.

This study focus on management as the framework for leadership abilities application. It is appropriate that the person of leader in company, also master corresponding elements of management abilities. Given the interdependence, but also many differences between these two mentioned concepts are discussed the opinions among foremost scientists.

In conclusion, the submitted study deals with the development of management and leadership in the context of historical events and their related scientific theories. Now these two concepts are in business practice considerable overlapping, but use different tools, that should be used appropriately to achieve a balance among them.

\section{Literature:}

1. BARNARD, C. L. The nature of leadership. SD Hoslett, 1948. 2. BARNARD, C. L. The functions of the executive. Harvard University Press, Cambridge, MA, 1938.

3. BASS, B. M. Does the transactional - transformational leadership paradigm transcend organizational and national boundaries? American Psychologist, 1997. 52 (2), 130-139.

4. BASS, B. M. Leadership and performance beyond expectation. New York: Free Press, 1985.

5. BASS, B. M., Avolio, B. J., \& Goodheim, L. Biography and the assessment of transformational leadership at the world class level. Journal of Management, 1987. 13, 7-19.

6. BIRD, C. Social psychology. Appleton-Century, New York, 1940. 7. BĚLOHLÁVEK, F. Organizačni chování: jak se každý den chovaji spolupracovnici, nadřizení, podřizení, obchodní partneři či zákazníci. 1. vyd. Olomouc: Rubico, 1996. 343 s. ISBN 80-8583909-1.

8. BLÁHA, J. Pokročilé řizení lidských zdrojů. 1. vyd. Brno: Edika, 2013. 264 s. ISBN 978-80-266-0374-0.

9. BLAŽEK, L. Management: organizování, rozhodování, ovlivňování. 2., rozš. vyd. Praha: Grada, 2014. 211 s. ISBN 978-80247-4429-2.

10. BORGATTA F. E., R. F. Bales and A. S. COUCH.: American Sociological Review. Vol. 19, No. 6 (Dec., 1954), pp. 755-759. 11. BROWN, M. E., TREWINO, L. K. Ethical leadership: A review of future directions. The leadership quarterly, 2006. 17, 595-616. 12. BURNS, J.M. Leadership. New York: Harper \& Row, 1978. 13. CARLYLE, T. "On heroes, hero-worship and the heroic", in Fredrick, A. History, Stokes \& Brother, New York, NY, 1888. p. 2. 14. CRAINER, S. Moderní management: Základní myšlenkové směry. Vyd. 1. Praha: Management Press, 2000. 250 s. ISBN 807261-019-8.

15. CUNNINGHAM \& W.J. GEPHART (Eds.), Leadership: The science and art today, 1977. pp. 139-164. Itaska, IL: F.E. Peacock Publishers.

16. DANSEREAU, F., STEPHANIE R. S., CHIA-YEN CHIU, SHAUGHNESSY, B., F. J. YAMMARINO, What makes leadership, leadership? Using self-expansion theory to integrate traditional and contemporary approaches, The Leadership Quarterly, Vol 24, Iss 6, 2013, Pp. 798-821, ISSN 1048-9843.

17. FIELD, R.H. A critique of the Vroom-Yetton contingency model of leadership behavior. Academy of Management Review, 4,1979. pp. 249-257.

18. FRY, L. W. Toward a theory of spiritual leadership. The Leadership Quarterly, 2003. 14, 693-727.

19. FUCHS, K., LISÝ, J. Dějiny ekonomického myšleni I. 1. vyd. Brno: Masarykova univerzita, 2007. 111 s. ISBN 978-80-210-44791.

20. GARDNER, W. L., AVOLIO, B. J., LUTHANS, F., MAY, D. R., \& WALUMBWA, F. Can you see the real me? A self-based model of authentic leader and follower development. The Leadership Quarterly, 2005. 16, 243-27
21. GERŠLOVÁ, J., ŽÁK, M. Dějiny podnikání. Vyd. 1. Praha: Vysoká škola ekonomie a managementu, 2012. 120 s. ISBN 978-8086730-95-0.

22. HENCLEY, S.P. Situational behavioral approach to the study of educational leadership. In L. C, 1973

23. HOLMAN, R. Dějiny ekonomického myšlení. 2. vyd. Praha: C. H. Beck, 2001. 541 s. ISBN 80-7179-631-x.

24. HOUSE, R.J. A path goal theory effectiveness. Administration Science Quarterly, 1971. 16, 321-338.

25. HOY, W.K. \& MISKEL, C.G. Educational administration: Theory, research, and practice. Third Edition. New York: Random House, 1987.

26. HÁLEK, I. Český management v evropské kultuře: hledáni východisek z krize současné společnosti na základě historickoteologické analýzy. Brno: Tribun EU, 2014. 230 s. ISBN 978-80263-0718-1.

27. KAREŠ, J., DRLÍKOVÁ, M., BRABCOVÁ, I. Moderní metody v řizení. 1. vyd. České Budějovice: Jihočeská univerzita v Českých Budějovicích, Zdravotně sociální fakulta, 2006. 137 s. ISBN 807040-852-9.

28. KENNEDY, C. Guide to the Management Gurus. Shortcuts to the Ideas of Leading Management Thinkers. 1991. Random Century Lim. London

29. KETS D. V., MANFRED, F., FLORENT E. Noví globální lídři. Richard Branson, Percy Barnevik, David Simon. Vyd. 1. Praha: Management Press, 2001. 171 s. ISBN 80-7261-044-9.

30. KOONTZ, H. Management. Praha: East Publishing, 1998. 659 s. ISBN 80-7219-014-8.

31. KOTTER, J. P. A force for change: how leaderhip differs from management. New York: Free Press, 1990. 180 s. ISBN 0-02918465-7.

32. LEWIN, K. A Dynamic Theory of Personality, McGraw Hill, New York, NY, 1935

33. LEWIN, K. A Research Approach to Leadership Problems. Journal of Educational Sociology Vol. 17, No. 7, Leadership In Democracy, 1944. pp. 392-398.

34. LUKAS, J., SMOLÍK, J. Psychologie viddcovství. Vyd. 1. Brno: Computer Press, 2008. 206 s. ISBN 978-80-251-2139-9.

35. MANN, R. D. A review of the relationships between personality and performance in small groups. Psychological Bulletin, 56, 1959. pp. 241-270.

36. MASLOW, A. H. A Theory of Human Motivation. Psychological Review, 1943. 50, 370-396.

37. MAYO, Elton. human problems of an industrial civilization. 1933.

38. McELROY, C. J. A Typology of Attribution Leadership Research. ACAD MANAGE REV, 1982. 7:3 413-417.

39. McGREGOR, D. The Human Side of Enterprise, New York, McGrawHill. 1960.

40. MESSICK, D. M., KRAMER, R. M. The psychology of leadership: New perspectives and research, 2005. Mahwah, N. J.: L. Erlbaum associates.

41. NĚMEČEK, P., ZICH, R. Podnikový management. Vyd. 1. Brno: Akademické nakladatelství CERM, 2004. 60 s. ISBN 80-2142779-5.

42. NĚMEČEK, P., ZICH, R. Podnikový management II: historie a současnost. Vyd. 1. Brno: Akademické nakladatelství CERM, 2008. 75 s. ISBN 978-80-214-3626-8.

43. POOR, H. V. History of Railroads and Canals in the United States, 1860.

44. REAVE, L. Spiritual values and practices related to leadership effectiveness. The Leadership Quarterly, 2005. 16, 655-687.

45. RICARDO, D., MILL, S. On the Principles of Political Economy and Taxation, 1817.

46. SCOTT, J. The concise handbook of management: a practitioner's approach. Binghamton, NY: Haworth Business Press, 2005. 258 p. ISBN 0789026481.

47. STOGDILL, R. M. Leadership, membership and organization. Psychological Bulletin, 47, 1950. pp. 1-14.

48. SLÁDEK, P. Sociologie a podnikání. 1. vyd. V Praze: České vysoké učení technické, 2013. 112 s. ISBN 978-80-01-05178-8.

49. SMITH, A. An Inquiry into the Nature and Causes of the Wealth of Nations, 1776.

50. SOJKA, M. Dějiny ekonomických teorií. 1. vyd. Praha: Karolinum, 2000. 298 s. ISBN 80-7184-991-x. 
51. SOJKA, M. a KADEŘÁBKOVÁ, B. Stručné dějiny ekonomických teorií. 1. vyd. Praha: Eupress, 2004. 95 s. ISBN 8086754-15-4.

52. STÖRIG, H. J. Malé dějiny filosofie. Vyd 8., V KNA 2. Kostelní Vydř́: Karmelitánské nakladatelství, 2007. 653 s. ISBN 978-807195-206-0.

53. STEIGAUF, S. Vůdcovství, aneb, Co vás na Harvardu nenaučí. 1. vyd. Praha: Grada, 2011. 368 s. ISBN 978-80-247-3506-1.

54. YAMMARINO, F. J., S. D. DIONNE, J. U. CHUN, F. DANSEREU.: Leadership and levels of analysis: A state-of-thescience review. Leadership Quarterly, 16, 2005. pp. 879-919.

Primary Paper Section: A

Secondary Paper Section: AB, AH 